\title{
Inter-Laboratory collation testing as a method of improvement of objectivity of technical expertise
}

\author{
(C) Alexey P. Belyaev ${ }^{1,2}$ \\ ${ }^{1}$ Department of Physical and Colloidal Chemistry. St. Petersburg State Chemical-Pharmaceutical University. \\ Professor Popov St., 14. Petersburg, 197376. Russia. \\ ${ }^{2}$ Department "Forensic examination of substances, materials and products" Peter the Great St. Petersburg \\ Polytechnic University. Polytechnicheskaya St., 29. Petersburg, 195251. Russia. \\ Phone: +7 (812) 499-39-00,41-41.E-mail: Alexei.Belyaev@pharminnotech.com
}

Keywords: medicinal substances, food products, methods for improving the quality of medicinal substances, improving the competence of experimental laboratories, interlaboratory comparison tests, mathematical methods of analysis, regulatory framework for interlaboratory comparison testing.

\begin{abstract}
The results of the interlaboratory comparison tests of experimental laboratories that analyzed vodka produced and sold in the Russian Federation for human consumption are presented in order to demonstrate the capabilities of the comparison tests. The choice of vodka as a model object was determined, on the one hand, by its definite proximity to medicinal substances, and on the other, by its assignment as food product, for which the regulatory framework for interlaboratory comparison tests was developed in sufficient detail. The following controlled indicators were examined: strength, alkalinity, mass concentration of acetaldehyde, mass concentration of acetic aldehyde, mass concentration of fusel oil, mass concentration of esters (methyl acetate, ethyl acetate), volume fraction of methyl alcohol in terms of anhydrous alcohol. 30 experimental laboratories are involved in the interlaboratory comparison tests. All participants guided by the same regulatory documents. The test results are processed statically in accordance with the regulatory framework developed for food products. It demonstrated that the majority of participants in the interlaboratory comparison tests successfully coped with the task of testing vodka under the conditions of reproducibility of the analytical method, and recommendations were made to correct the activities of testing laboratories for the rest. The diagrams were constructed to demonstrate visually checks on the quality of tests in determining strength, in determining alkalinity, in determining the mass concentration of acetic aldehyde, in determining the mass concentration of fusel oil and in determining the volume fraction of methyl alcohol in terms of anhydrous alcohol.

The results of statistical processing allowed to state that interlaboratory comparison tests correctly and visually assess the competence of the activities of experimental laboratories, allow to plan actions preventive violations in the objectivity of the work of experimental laboratories. It is shown that the introduction of the practice of experimental laboratories working in the field of production and circulation of medicinal substances, interlaboratory comparison tests can be one of the possible ways to improve the quality of medicinal substancesThe opinion was expressed that for testing interlaboratory comparison tests in the production and circulation of medicinal substances one can use the regulatory framework developed for food products.
\end{abstract}

\section{References}

[1] A.P. Belyaev, V.P. Rubets, V.V. Antipov, A.O. Ribnikov, and S.A. Belyaeva. Crystallization of paracetamol of rhombic form. Butlerov Communications. 2014. Vol.37. No.3. P.113-119. ROI: jbc02/14-37-3-113

[2] A.P. Belyaev, V.P. Rubets, V.V. Antipov, and E.Yu. Pavlova. Stability of crystalline structure of paracetamol's molecular crystals generated by calorimetric scanning. Butlerov Communications. 2017. Vol.51. No.8. P.105-110. DOI: 10.37952/ROI-jbc-01/17-51-8-105

[3] A.P. Belyaev, N.S. Bordei, V.P. Rubets, V.V. Antipov. Formation of the molecular crystal structure during the vacuum sublimation of paracetamol. Russian Journal of Physical Chemistry A. 2015. Vol.89. No.4. P.575-579.

[4] A.P. Belyaev, V.P. Rubets, V.V. Antipov. Influence of temperature on the rhombic shape of paracetamol molecular crystals Technical Physics. Russian Journal of Applied Physics. 2017. Vol.62. No.4. P.645647. 
INTER-LABORATORY COLLATION TESTING AS A METHOD OF IMPROVEMENT OF OBJECTIVITY...

[5] Order of Ministry of Health of Russian Federation from 13.02.2013 No.66 (ed. 07.04.2016 "About approval of the Strategy for Drug provision of the population of the Russian Federation for the period up to 2025 and the plan for its implementation").

[6] Interstate standard adopted by Euro-Asian council for standardization, metrology and certification (Protocol of 7 June 2013 N 43) GOST 12712-2013 Vodkas and special vodkas. General specifications.

[7] The national standard of the Russian Federation, approved and enacted by the Order of the Federal Agency for Technical Regulation and Metrology from 12 November 2010 N 440-st, GOST ISO 13528. Statistical methods. Using in proficiency testing by interlaboratory comparison tests.

[8] Interstate standard adopted by Euro-Asian council for standardization, metrology and certification (Protocol of 7 June 2013 N 43), GOST 32035-2013. Vodkas and special vodkas. Acceptance rules and test methods.

[9] Interstate standard adopted by Euro-Asian council for standardization, metrology and certification (Protocol of 7 June 2013 N 43), GOST 32036-2013. Vodka and ethanol from food raw material. Gaschromatographic express-method for determination of toxic microadmixtures content.

[10] Interstate standard adopted by Euro-Asian council for standardization, metrology and certification (Protocol of 19 May 2013 N 56-P), ISO/IEC 17043-2013. Conformity assessment. General requirements for proficiency testing.

[11] Recommendations on interstate standardization adopted by Euro-Asian council for standardization, metrology and certification (Protocol of 25 November 2010 N 38), Recommendations on interstate standardization 103-2010. State system for ensuring the uniformity of measurements. Proficiency testing of test (measurement) laboratories, conducting the tests of substances, materials and environmental objects (for composition and physico-chemical properties) by means of interlaboratory comparisons.

[12] Recommendations on interstate standardization adopted by Euro-Asian council for standardization, metrology and certification (Protocol of 25 June 2014 N 45), Recommendations on interstate standardization 76-2014. State system for ensuring the uniformity of measurements. Internal control of quantitative chemical analysis result's accuracy.

[13] Recommendations on interstate standardization adopted by Euro-Asian council for standardization, metrology and certification (Protocol of 22 May 2003 N 23), Recommendations on interstate standardization 58-2003. State system for ensuring the uniformity of measurements. Evaluation of the working quality of foodstuff testing laboratory. Methods for development of the external control of test results accuracy.

[14] State standard of the Russian Federation adopted and enacted by decree of State Committee of the Russian Federation on Standardization and Metrology 23 April 2002 N 161-st, GOST R ISO- IEC 5725-1-2002. Accuracy (trueness and precision) of measurement methods and results. Part 1. General principles and definitions.

[15] State standard of the Russian Federation adopted and enacted by decree of State Committee of the Russian Federation on Standardization and Metrology 23 April 2002 N 161-st, GOST R ISO- IEC 5725-2-2002. Accuracy (trueness and precision) of measurement methods and results. Part 2. Basic method for the determination of repeatability and reproducibility of a standard measurement method.

[16] State standard of the Russian Federation adopted and enacted by decree of State Committee of the Russian Federation on Standardization and Metrology 23 April 2002 N 161 -st, GOST R ISO- IEC 5725-3-2002. Accuracy (trueness and precision) of measurement methods and results. Part 3. Intermediate measures of the precision of a standard measurement method.

[17] State standard of the Russian Federation adopted and enacted by decree of State Committee of the Russian Federation on Standardization and Metrology 23 April 2002 N 161-st, GOST R ISO- IEC 5725-4-2002. Accuracy (trueness and precision) of measurement methods and results. Part 4. Basic methods for the determination of the trueness of a standard measurement method.

[18] State standard of the Russian Federation adopted and enacted by decree of State Committee of the Russian Federation on Standardization and Metrology 23 April 2002 N 161-st, GOST R ISO- IEC 5725-5-2002. Accuracy (trueness and precision) of measurement methods and results. Part 5. Alternative methods for the determination of the precision of a standard measurement method.

[19] State standard of the Russian Federation adopted and enacted by decree of State Committee of the Russian Federation on Standardization and Metrology 23 April 2002 N 161-st, GOST R ISO- IEC 5725-6-2002. Accuracy (trueness and precision) of measurement methods and results. Part 6. Use in practice of accuracy values.

[20] The national standard of the Russian Federation adopted and enacted by decree of State Committee of the Russian Federation on Standardization and Metrology ot 27 January 2004 N 34-st, GOST R ISO 
16269-7-2004. Statistical methods. Statistical interpretation of data. Median. Estimation and confidence intervals.

[21] Recommendations on interstate standardization adopted by Euro-Asian council for standardization, metrology and certification (Protocol of 2 November 2001 N 20), Recommendations on interstate standardization 43-2001. State system for ensuring uniformity of measurements. Application of the "Guide to the expression of uncertainty of measurement." 